Abstracta Iranica Abstanica

Revue bibliographique pour le domaine irano-aryen

Volume 24 | 2003

Comptes rendus des publications de 2001

\title{
«Les Actes de Mar Mari : une figure apocryphe au service de l'unité communautaire ». Apocrypha 10, (1999), pp. 177-193.
}

Simon C. Mimouni

\section{(2) OpenEdition}

1 Journals

\section{Édition électronique}

URL : http://journals.openedition.org/abstractairanica/34474

DOI : 10.4000/abstractairanica.34474

ISSN : 1961-960X

Éditeur :

CNRS (UMR 7528 Mondes iraniens et indiens), Éditions de l'IFRI

\section{Édition imprimée}

Date de publication : 15 mai 2003

ISSN : 0240-8910

\section{Référence électronique}

Simon C. Mimouni, « «Les Actes de Mar Mari : une figure apocryphe au service de l'unité communautaire ». Apocrypha 10, (1999), pp. 177-193. », Abstracta Iranica [En ligne], Volume $24 \mid 2003$, document 153, mis en ligne le 05 janvier 2010, consulté le 25 septembre 2020. URL : http:// journals.openedition.org/abstractairanica/34474 ; DOI : https://doi.org/10.4000/abstractairanica. 34474

Ce document a été généré automatiquement le 25 septembre 2020.

Tous droits réservés 


\title{
«Les Actes de Mar Mari : une figure apocryphe au service de l'unité communautaire ». Apocrypha 10, (1999), pp. 177-193.
}

\author{
Simon C. Mimouni
}

La figure de Mari, apôtre de la Mésopotamie du Sud, apparaît dans le texte hagiographique syriaque des Actes de Mar Mari - de la fin du $6^{\mathrm{e}}$ ou début du $7^{\mathrm{e}}$ s. comme la figure emblématique des communautés chrétiennes de l'Empire iranien. Ce personnage fondateur de communautés est apparenté au groupe des 70 disciples de Jésus et sa geste missionnaire, qui s'inscrit à la suite des grands apôtres Thomas, Pierre et Paul, l'identifie au Christ lui-même, selon une thématique gémellaire bien connue dans la littérature chrétienne de langue syriaque. Mar Mari apparaît ainsi comme le garant de l'unité interne de l'Eglise nestorienne face aux menaces centripètes, fonctionnant aussi en véritable palladium contre toute déviance doctrinale - il est présenté en effet comme l'agent essentiel d'une reconquête active à l'égard du principal danger pour les communautés locales babyloniennes, le manichéisme. L'étude permet de dégager des niveaux historiques de rédaction et, partant, des strates de relecture des origines du christianisme en Babylonie, alors sous domination sassanide.

\section{INDEX}

Thèmes : 6.3. Autres religions 
AUTEURS

SIMON C. MIMOUNI

EPHE - Paris 